\title{
Optimasi Kombinasi Pati Umbi Gembili (Dioscorea esculenta (Lour.) Burk) dan Umbi Ganyong (Canna edulis Ker.) Sebagai Bahan Pengisi Tablet Ibuprofen dengan Metode Simplex Lattice Design
}

\author{
Nailul Maghfiroh ${ }^{1}$, Dian E.Ermawati ${ }^{*}$, Sholichah Rohmani ${ }^{1}$ \\ ${ }^{1}$ Program Studi S1 Farmasi, Fakultas Matematika dan Ilmu Pengetahuan Alam, Universitas Sebelas Maret \\ *email korespondensi : dianekaerma@gmail.com
}

\begin{abstract}
Abstrak: Pati umbi gembili dan ganyong merupakan bahan pangan yang belum banyak pemanfaatannya dalam bidang farmasi terutama sebagai bahan pengisi tablet. Tablet masih populer sebagi sistem penghantaran obat di masyarakat. Penggunaan pati umbi, sebagai bahan pengisi memberikan gagasan baru dan diharapkan dapat mengurangi efek samping ibuprofen pada lambung, yang biasanya dikonsumsi bersamaan dengan makanan. Tujuan dari penelitian ini untuk mengetahui proporsi kombinasi optimum campuran pati gembili-ganyong yang menghasilkan sifat fisik granul, tablet dan disolusi sesuai persyaratan tablet yang baik. Optimasi proporsi pati gembili-ganyong menggunakan metode Simplex Lattice Design dengan Software Design Expert. Tablet ibuprofen dibuat dengan metode granulasi basah dalam 8 formula dari SLD dengan respon stabilitas fisik : waktu alir, keseragaman bobot, dan waktu hancur. Formula dengan respon tertinggi merupakan formula optimum. Hasil pengujian formula optimum dengan hasil prediksi $S L D$ dilakukan uji statistika menggunakan analisa statistika uji-t, selanjutnya dilakukan uji disolusi. Hasil optimasi menunjukkan nilai perbandingan pati umbi gembiliganyong yang optimum adalah $82,11 \%: 17,89 \%$. Hasil analisa statistika uji-t dari formula optimum dengan formula prediksi $S L D$ tidak terdapat perbedaan yang signifikan dengan nilai pvalue $>0,05$. Hasil sifat fisik formula optimum ibuprofen meliputi; waktu alir sebesar 4,92 detik $\pm 0,46$ dan sudut diam $26,96^{\circ} \pm 1,35$; keseragaman tablet $501,72 \mathrm{mg} \pm 2,29$; kekerasan 7,45 $\mathrm{Kg} \pm$ 0,38 ; kerapuhan $0,81 \% \pm 0,01$; waktu hancur 9,16 menit $\pm 0,75$; kadar zat aktif tablet $92,49 \%$ $105,76 \%$ dan uji disolusi dengan nilai DE\% sebesar 78,25\%.
\end{abstract}

Kata kunci: Pati gembili-ganyong; Tablet ibuprofen; Simplex Lattice Design

Abstract. Optimization Combination of Starch Tuber Gembili (Dioscorea esculenta (Lour.) Burk) and Tuber Ganyong (Canna edulis Ker.) as Filler of Ibuprofen Tablet by Simplex

Lattice Design Method. Gembili tuber starch and Ganyong are foodstuffs that have not been widely used in the pharmaceutical product, especially as tablet fillers. Tablets are still popular as a drug delivery system in the community. Using of tuber starch, as a tablets filling provides new ideas and is expected to reduce the side effects of ibuprofen on the stomach, which is usually consumed along with food. The purpose of this study was to determine the proportion of the optimum combination of Gembili-Ganyong starch in mixture that produces physical properties of granules, tablets and dissolution according to the requirements of a good tablet. Optimization of proportions of Gembili-Ganyong starch using Simplex Lattice Design method with Software Design Expert. Tablets of ibuprofen were made by wet granulation method in 8 formulas from SLD with physical stability response : flow time, weight uniformity, and disintegration time. The 
formula with the highest response is the optimum formula. The optimum formula test results with SLD prediction results were performed statistical tests using statistical analysis of the t-test, then the dissolution test was carried out. The optimization results showed that the optimum ratio of Gembili-Ganyong tuber starch was $82.11 \%: 17.89 \%$. The results of statistical analysis of the ttest of the optimum formula with SLD prediction formula did not have a significant difference with p-value $>0.05$. The results of the physical properties of the optimum formula for ibuprofen : flow time is 4.92 seconds \pm 0.46 and the stationary angle is $26.960^{\circ} \pm 1.35$; tablet uniformity $501.72 \mathrm{mg} \pm 2.29$; hardness of $7.45 \mathrm{Kg} \pm 0.38$; fragility $0.81 \% \pm 0.01$; disintegration time of 9.16 minutes \pm 0.75 ; ibuprofen content was $92.49 \%-105.76 \%$ and dissolution test with DE\% value of $78.25 \%$.

Keywords: Tuber starch gembili and ganyong; Ibuprofen Tablet; Simplex Lattice Design

\section{Pendahuluan}

Indonesia kaya akan sumber penghasil pati, namun pemanfaatan pati sebagai bahan eksipien pada industri farmasi masih sangat terbatas. Sayangnya, selama ini industri farmasi masih menggunakan amilum yang diimpor untuk memenuhi kebutuhan eksipien. Pati terdiri dari dua fraksi, yaitu fraksi terlarut dan tidak terlarut. Fraksi terlarut disebut amilosa dan fraksi yang tidak terlarut disebut amilopektin. Pada umumnya pati mengandung amilopektin lebih banyak dibanding amilosa. Perbandingan amilosa dan amilopektin ini mempengaruhi sifat kelarutan dan derajat gelatinasi pati. Kandungan amilosa yang bertanggungjawab membuat sifat pati kering dan kurang lengket (Rohmah, 2013).

Menurut penelitian Richana (2012) umbi gembili (Dioscorea esculenta (Lour.) Burk) memiliki kadar amilosa 12,47\%, sedangkan ganyong (Canna edulis Ker.) memiliki kadar amilosa $10,45 \%$. Kandungan kadar amilosa yang terdapat pada kedua tanaman tersebut cukup memnuhi persyaratan dan berpotensi untuk dikembangkan sebagai bahan pengisi sekaligus pengikat. Melihat potensi bahan alam yang dapat digunakan sebagai eksipien khususnya bahan pengisi, dilakukan pengembangan formula sediaan tablet. Tablet merupakan sediaan farmasi yang praktis dalam penyimpanan dan pemakaiannya, stabilitas obatnya lebih terjamin, memberikan takaran dosis zat aktif yang seragam serta mudah dibawa kemana-mana (Lachman dkk., 2008).

Bahan pengisi selain berfungsi untuk memperbesar volume tablet, juga menjamin tablet mempunyai ukuran yang seragam serta memperbaiki daya kohesi sehingga dapat dikempa langsung atau untuk memacu aliran. Jumlah bahan pengisi yang dibutuhkan bervariasi, berkisar 5-80\% dari bobot tablet (tergantung jumlah tablet dan bobot tablet yang diinginkan). Tablet dengan bahan aktif berdosis kecil, sifat tablet secara keseluruhan ditentukan oleh sifat bahan pengisi (Ansel dkk., 2013). Ibuprofen adalah obat antiinflamasi non steroid (NSAID) yang 
digunakan untuk menghilangkan tanda dan gejala rheumatoid arthritis, pereda rasa nyeri ringan hingga sedang, serta digunakan pada kondisi nyeri kronis akut ataupun pembengkakan (Wilmana dan Gan, 2007). Ibuprofen dalam Biopharmaceutical Classification System (BCS) termasuk kelas II atau obat dengan kelarutan rendah, tetapi memiliki permeabilitas yang tinggi (Ferdiansyah dkk., 2017).

Metode Simplex Lattice Design (SLD) dapat digunakan untuk optimasi formula pada berbagai jumlah komposisi bahan yang berbeda sehingga menghasilkan formula optimum yang memiliki sifat fisik yang diharapkan. Tujuan penggunaan metode ini untuk menentukan konsentrasi bahan yang tepat sehingga didapatkan formula yang memiliki sifat fisik yang optimum dan respon yang diterima oleh konsumen. Metode ini cepat praktis karena dapat menghindarkan penentuan formula secara coba-coba (trial and error). Berdasarkan uraian tersebut, peneliti melakukan optimasi proporsi komposisi optimum pati gembili dan pati ganyong pada tablet ibuprofen dengan metode Simplex Lattice Design (SLD) berdasarkan tiga respon sifat fisik yaitu waktu alir, keseragaman bobot, dan waktu hancur. Diharapkan dapat menghasilkan tablet ibuprofen berbahan dasar pengisi dari bahan alam dan memenuhi kriteria tablet ibuprofen yang baik.

\section{Bahan dan Metode}

Bahan yang digunakan dalam penelitian ini yaitu umbi gembili, umbi ganyong, Ibuprofen (PT Konimex), metanol (teknis), magnesium stearat, talkum, gelatin, amprotab, aquadest, $\mathrm{NaOH}$ dan kalium fosfat monnobasa (semua bahan penyusun tablet dengan kualitas farmasetis Bratachem).

Alat yang digunakan dalam penelitian ini yaitu neraca analitik (Precisia BJ 401c dan Sartorius BP 221S), hardness tester, friability tester, jangka sorong, ayakan 90 mesh, ayakan 16 mesh, ayakan 18 mesh, oven, stopwatch, mesin tablet single punch (TD, Shanghai Tianhe Pharmaceutical Machinery), dissolution tester tipe dayung (Guoming RC-1), spektrofotometer UV-Vis (Genesys $\left.{ }^{\mathrm{TM}} 10 \mathrm{~s}\right)$, serta alat-alat gelas dan alat pendukung lainnya

\subsection{Determinasi tanaman}

Umbi gembili (Dioscorea esculenta (Lour.) Burk) dan umbi Ganyong (Canna edulis Ker.) dipanen di daerah Kaliwungu, Kendal, Jawa Tengah, Indonesia pada bulan Februari 2018. Umbi selanjutnya dilakukan determinasi di Laboratorium Biologi Fakultas Matematika dan Ilmu Pengetahuan Alam Universitas Sebelas Maret Surakarta. Determinasi tanaman bertujuan untuk menjamin kebenaran tanaman yang digunakan. 


\subsection{Penyiapan dan pembuatan pati}

Umbi gembili dan umbi ganyong masing-masing 3,0 Kg kemudian diawali dengan sortir umbi, mengupas kulit, pencucian, dan pemarutan. Hasil parutan kemudian dicuci dengan air sebanyak 2 kali (1:3 dan 5:3). Dilakukan penyaringan dan didapatkan ampas pati, selanjutnya diendapkan 6-12 jam. Pati yang basah kemudian dikeringkan dalam oven $50^{\circ} \mathrm{C}$ selama 6 jam hingga kering kemudian diayak menggunakan ayakan berukuran 90 mesh (Richana dan Sunarti, 2004).

\subsection{Pembuatan tablet}

Formula talet dibuat dengan bobot $500 \mathrm{mg}$, dari Software DX dengan metode SLD didapatkan delapan formula dengan dosis ibuprofen $200 \mathrm{mg}$ tiap tabletnya. Kombinasi kedua pati gembili dan pati ganyong, ibuprofen, amprotab dicampur, ditambahkan gelatin 5\% b/v sedikit demi sedikit ke dalam campuran hingga terbentuk massa granul. Massa granul basah diayak menggunakan ayakan 16 mesh, dikeringkan dalam oven pada suhu $60^{\circ} \mathrm{C}$ selama 5 jam. Granul kering diayak dengan ayakan 18 mesh. Rancangan formulasi tablet seperti pada Tabel 1.

\subsubsection{Waktu alir granul}

Sejumlah 100 gram granul dimasukkan kedalam corong kemudian dibuka penutup corong lalu catat waktu granul mengalir dengan stopwatch (Suihko dkk., 2001).

\subsubsection{Sudut Diam}

Diameter dan tinggi tumpukan kerucut dari 50 gram granul yang terbentuk dengan mengalirkan granul melalui corong diukur dan dihitung besar sudut diam granul (Suihko dkk., 2001).

\subsubsection{Pentabletan}

Penabletan menggunakan mesin tablet single punch, berat tablet adalah $500 \mathrm{mg}$, punch atas dan punch bawah diatur sedemikian rupa sehingga didapatkan bobot tablet yang diinginkan.

\subsubsection{Keseragaman Bobot}

Sejumlah 20 tablet dan ditimbang satu per satu. Dihitung bobot rata - rata tablet dan hitung persen penyimpangan bobot tablet, tidak boleh lebih dari dua tablet yang masing-masing bobotnya menyimpang dari bobot rata-ratanya lebih besar dari harga yang ditetapkan kolom $\mathrm{A}$ dan tidak satu tabletpun yang bobotnya menyimpang dari bobot rata-ratanya lebih dari harga yang ditetapkan kolom B (FI Edisi III, 1979). 


\subsubsection{Kekerasan Tablet}

Alat yang digunakan ialah hardness tester. Cara kerjanya yaitu sebuah tablet diletakk tegak lurus diantara anvil dan punch, tablet dijepit dengan cara memutar sekrup pengatur sampai tanda lampu stop menyala. Lalu knop ditekan sampai tablet pecah. Angka yang ditunjukkan jarum penunjuk skala dibaca. Persyaratan kekerasan tablet 4-8 kg (Ansel dkk., 2013).

\subsubsection{Kerapuhan Tabet}

Dua puluh tablet dibersihkan dari debu, ditimbang, kemudian dimasukkan ke dalam alat uji kerapuhan (friabilator). Alat diputar pada kecepatan $25 \mathrm{rpm}$ selama 4 menit. Seluruh tablet dikeluarkan, dibersihkan dari debu dan ditimbang kembali. Dihitung kehilangan bobot dalam prosentase. Syarat < 1\% (Lachman, 2008).

\subsubsection{Waktu Hancur Tablet}

Enam tablet dimasukkan ke dalam keranjang, kemudian keranjang diturun-naikkan secara teratur pada suhu $37 \pm 0,5^{\circ} \mathrm{C}$. Tablet tidak bersalut dikatakan baik apabila waktu hancurnya kurang dari 15 menit (Depkes RI, 2014). Waktu hancur yang cepat dan sempurna memberi persyaratan yang baik untuk ketersediaan obat.

Tabel 1. Formula Tablet Didapat dari Batas atas dan Batas Bawah (0:100) pada Software DX dengan metode Simplex Lattice Design

\begin{tabular}{|l|c|c|c|c|c|c|c|c|}
\hline \multirow{3}{*}{ Bahan (mg) } & \multicolumn{9}{|c|}{ Formula } \\
\cline { 2 - 9 } & $\begin{array}{c}\text { I } \\
\end{array}$ & II & III & IV & V & VI & VII & VIII \\
\hline Pati Gembili & 125 & 125 & 250 & - & 187,5 & - & 250 & 62,5 \\
\hline Pati Ganyong & 125 & 125 & - & 250 & 62,5 & 250 & - & 187,5 \\
\hline Ibuprofen & 200 & 200 & 200 & 200 & 200 & 200 & 200 & 200 \\
\hline Amprotab & 25 & 25 & 25 & 25 & 25 & 25 & 25 & 25 \\
\hline Gelatin & 10 & 10 & 10 & 10 & 10 & 10 & 10 & 10 \\
\hline Mg Stearat & 5 & 5 & 5 & 5 & 5 & 5 & 5 & 5 \\
\hline Talkum & 10 & 10 & 10 & 10 & 10 & 10 & 10 & 10 \\
\hline Total & 500 & 500 & 500 & 500 & 500 & 500 & 500 & 500 \\
\hline
\end{tabular}

\subsection{Penetapan kadar tablet}

\subsubsection{Penetapan kadar zat aktif ibuprofen}

Penentuan panjang gelombang : Larutan induk ibuprofen dibuat dengan cara melarutkan

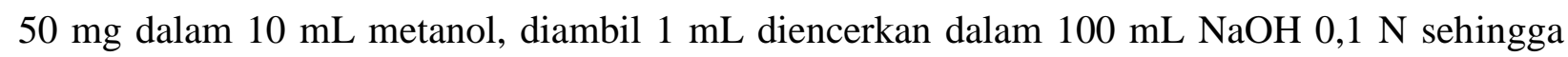
diperoleh konsentrasi $1000 \mu \mathrm{g} / \mathrm{mL}$. Dari larutan induk diukur serapan larutan ibuprofen dengan konsentrasi $32 \mu \mathrm{g} / \mathrm{mL}$ pada panjang gelombang 200-400 $\mathrm{nm}$ dengan menggunakan spektrofotometer UV-VIS. Kemudian dibuat kurva serapan terhadap panjang gelombang. 
Pembuatan kurva kalibrasi Ibuprofen dalam $\mathrm{NaOH}$ 0,1 $\mathrm{N}$ : Larutan standard ibuprofen dalam $\mathrm{NaOH}$ 0,1 $\mathrm{N}$ dibuat dengan konsentrasi 12, 16, 20, 24, 28, dan $32 \mu \mathrm{g} / \mathrm{mL}$. Kemudian serapan ditentukan pada panjang gelombang maksimum.

Penetapan kadar Ibuprofen dalam tablet: Diambil 10 tablet secara acak, ditimbang dan tentukan bobot rata-ratanya. Kesepuluh tablet tersebut digerus sampai menjadi serbuk, kemudian ditimbang seberat bobot satu tablet yang setara $500 \mathrm{mg}$. Selanjutnya dilarutkan dalam $\mathrm{NaOH}$ 0,1 N dalam labu takar $100 \mathrm{~mL}$, dikocok sampai homogen, kemudian disaring. Filtrat pertama, filtrat selanjutnya ditampung. Lalu dipipet sebanyak 2,0 $\mathrm{mL}$ dan dimasukkan dalam labu ukur $10 \mathrm{~mL}$, kemudian tambahkan $\mathrm{NaOH}$ 0,1 $\mathrm{N}$ sampai tanda batas, kocok homogen. Absorbansinya diamati pada panjang gelombang maksimum $221 \mathrm{~nm}$ dengan menggunakan alat spektrofotometer UV-Vis. Menurut farmakope Indonesia Edisi V (2014), persyaratan kadar zat aktif dari tablet ibuprofen yaitu harus mengandung ibuprofen $\mathrm{C}_{13} \mathrm{H}_{18} \mathrm{O}_{2}$ tidak boleh kurang dari $90 \%$ dan tidak boleh lebih dari $110 \%$ dari jumlah yang tertera pada etiket.

\subsubsection{Profil disolusi tablet}

Media Disolusi: Media disolusi menggunakan dapar fosfat $\mathrm{pH}$ 7,2. Dapar ini dibuat dengan mencampurkan $50 \mathrm{~mL}$ kalium fosfat monobasa 0,2 $\mathrm{M}$ dengan 22,4 mL natrium hidroksida 0,2 M dan diencerkan dengan air hingga 200 Ml (Depkes RI, 2014).

Penetapan panjang gelombang ibuprofen : Sebanyak $50 \mathrm{mg}$ ibuprofen dilarutkan ke dalam $10 \mathrm{~mL}$ methanol, diambil $1 \mathrm{~mL}$ diencerkan ke dalam $100 \mathrm{~mL}$ dapar fosfat $\mathrm{pH}$ 7,2 hingga tanda batas, homogenkan didapatkan konsentrasi $50 \mu \mathrm{g} / \mathrm{mL}$. Larutan induk dipipet $16 \mathrm{~mL}$ dimasukkan kedalam labu ukur $25 \mathrm{~mL}$ dengan dapar fosfat $\mathrm{pH}$ 7,2 sampai tanda batas labu ukur sehingga diperoleh larutan dengan konsentrasi $32 \mu \mathrm{g} / \mathrm{mL}$. Serapan maksimum ibuprofen dalam larutan dapar fosfat pH 7,2 diukur pada panjang gelombang 200 - $400 \mathrm{~nm}$. Blanko yang digunakan dapar fosfat $\mathrm{pH} 7,2$.

Pembuatan kurva kalibrasi ibuprofen dalam medium dapar fosfat $\mathrm{pH}$ 7,2 : Dari larutan induk dilakukan pengenceran ibuprofen dengan dapar fosfat $\mathrm{pH} 7,2$ dengan konsentrasi 8,12 , 16, 24, 28 dan $32 \mu \mathrm{g} / \mathrm{mL}$.

Disolusi tablet : Dimasukkan medium disolusi sebanyak $900 \mathrm{~mL}$ ke dalam bejana disolusi kemudian dipanaskan hingga suhu $37^{\circ} \mathrm{C} \pm 0,5^{\circ} \mathrm{C}$. Tablet Ibuprofen dimasukkan ke dalam bejana disolusi kemudian diputar dengan kecepatan $50 \mathrm{rpm}$. Sampel diambil sebanyak $5 \mathrm{~mL}$ pada selang waktu $0,2,5,10,15,20,30,45$, dan 60 menit. Setiap sampel yang diambil lalu digantikan dengan medium disolusi sebanyak $5 \mathrm{~mL}$. Sampel yang diukur absorpsinya dan ditentukan kadarnya. 
Penetapan kadar: Penetapan kadar ibuprofen yang terlarut dengan menggunakan spektrofotometri UV pada panjang gelombang maksimum, yaitu $221 \mathrm{~nm}$. Dalam waktu 60 menit harus larut tidak kurang dari $80 \% \mathrm{C}_{13} \mathrm{H}_{18} \mathrm{O}_{2}$ dari jumlah yang tertera (Depkes RI, 2014).

$$
D E=\frac{\int_{0}^{t} Y \cdot d t}{\mathrm{Y} \cdot 100, \mathrm{t}} \times 100 \%
$$

\subsection{Analisis data}

Analisis data dilakukan dengan uji T-test (One sampel T-test) dengan taraf kepercayaan 95\%. Sampel uji dibandingkan dengan hasil prediksi SLD.

\subsection{Penentuan formula optimum berdasarkan Simplex Lattice Design}

Data respon sifat fisik granul dan tablet meliputi waktu alir, keseragaman bobot, waktu hancur dianalisis dengan metode Simplex Lattice Design. Masing-masing parameter tersebut akan diperoleh persamaan yang kemudian akan didapat proporsi koposisi formula yang optimum dengan nilai desirabiliti mendekati 1 (Bolton dan Bone, 2002).

\section{Hasil dan Pembahasan}

Hasil dan pembahasan ditulis dengan Times New Roman ukuran 12 dengan spasi 1.15. Hasil harus dituliskan jelas dan menggambarkan jawaban ilmiah, tidak sebatas hanya menampilkan data saja. Perbedaan hasil ataupun temuan baru dibandingkan penelitian sebelumnya lebih ditekankan. Hasil disertai tabel dan atau gambar.

\subsection{Determinasi tanaman}

Determinasi tumbuhan yang dilakukan menunjukkan bahwa tumbuhan dalam penelitian ini benar Dioscorea esculenta (Lour.) Burk dan Canna edulis Ker.

\subsection{Pembuatan Pati Gembili dan Ganyong}

Proses pengambilan pati dengan cara dicuci bersih, dikupas, diparut dan ditambah air 5:3 dari bahan yang digunakan. Diendapkan dan diambil patinya kemudian di oven dengan suhu $60^{\circ} \mathrm{C}$ selama 5 jam. Rendemen pati yang didapat sebanyak 11,40\% untuk pati gembili dan $12,30 \%$ untuk pati ganyong serta pengamatan organoleptik pati meliputi warna, tekstur, aroma, rasa dan ukuran granul pati (Tabel 2).

\subsection{Pembuatan Granul dan Uji Sifat Fisik}

Pada penelitian ini dibuat tablet ibuprofen dengan bobot tiap tablet adalah $500 \mathrm{mg}$. Metode yang digunakan adalah granulasi basah, metode ini baik digunakan untuk zat aktif yang memiliki sifat alir dan kopresibilitas yang tidak baik seperti ibuprofen. Perbandingan kombinasi bahan 
pengisi pati gembili dan pati ganyong pada masing-masing formula yaitu formula I dan II (50\% : $50 \%)$, formula III dan VII (100\% : $0 \%)$, formula IV dan VI ( $0 \%: 100 \%)$, formula VIII (25\%: $75 \%)$ dan formula V (75\%: 25\%). Dengan perbandingan penambahan bahan pengisi dimaksudkan untuk mengetahui kombinasi penggunaan pati gembili dan pati ganyong mana yang berpengaruh terhadap sifat fisik tablet ibuprofen. Pati dapat digunakan sebagai pengisi, pengikat dan penghancur (Lachman dkk., 2008). Optimasi tablet ibuprofen ini menggunakan parameter waktu alir, keseragaman bobot dan waktu hancur (Tabel 3).

Tabel 2. Karakteristik fisik pati gembili dan pati ganyong

\begin{tabular}{|c|c|c|c|}
\hline No. & Parameter & Pati Gembili & Pati Ganyong \\
\hline 1. & Warna & sedikit kemerahan & sedikit kemerahan \\
\hline 2. & Tekstur & Halus & halus \\
\hline 3. & Aroma & khas gembili & khas ganyong \\
\hline 4. & Rasa & Manis & manis \\
\hline 5. & Ukuran Granula Pati & $\begin{array}{c}\text { lebih kecil (lolos ayakan } 90 \\
\text { mesh })\end{array}$ & $\begin{array}{c}\text { lebih besar (lolos ayakan } \\
70 \text { mesh) }\end{array}$ \\
\hline
\end{tabular}

Tabel 3. Hasil uji sifat fisik granul dan tablet Ibuprofen formula optimum

\begin{tabular}{|c|c|c|c|c|c|c|c|c|}
\hline \multirow{2}{*}{ Sifat Fisik } & \multicolumn{7}{|c|}{ Formula } \\
\cline { 2 - 8 } & $\begin{array}{c}\text { I } \\
50: 50\end{array}$ & $\begin{array}{c}\text { II } \\
50: 50\end{array}$ & $\begin{array}{c}\text { III } \\
100: 0\end{array}$ & $\begin{array}{c}\text { IV } \\
0: 100\end{array}$ & $\begin{array}{c}\text { V } \\
75: 25\end{array}$ & $\begin{array}{c}\text { VI } \\
0: 100\end{array}$ & $\begin{array}{c}\text { VII } \\
100: 0\end{array}$ & $\begin{array}{c}\text { VIII } \\
25: 75\end{array}$ \\
\hline $\begin{array}{c}\text { Waktu alir } \\
\text { (detik) }\end{array}$ & 3,65 & 3,02 & 4,85 & 3,65 & 4,82 & 3,35 & 4,47 & 4,32 \\
\hline $\begin{array}{c}\text { Keseragaman } \\
\text { Bobot (mg) }\end{array}$ & 505,90 & 500,83 & 504,36 & 497,10 & 504,55 & 495,81 & 503,36 & 508,41 \\
\hline $\begin{array}{c}\text { Waktu Hancur } \\
\text { (menit) }\end{array}$ & 5,33 & 5,00 & 8,50 & 3,30 & 9,00 & 3,30 & 9,00 & 2,60 \\
\hline
\end{tabular}

\subsubsection{Waktu alir granul formula optimum}

Uji waktu alir granul dilakukan untuk mengetahui granul ibuprofen yang dibuat mempunyai sifat alir yang baik, karena sifat alir berpengaruh pada saat proses pengempaan. Granul dengan aliran yang kurang baik akan menyebabkan aliran granul dari hopper ke dalam die tidak sempurna, akibatnya granul yang dihasilkan tidak konstan. Dari delapan formula memiliki waktu alir formula (I dan II) kurang baik, formula (III dan VII) baik, formula (IV dan VI) kurang baik dan formula (V dan VIII) baik. Hasil tersebut menunjukkan bahwa komposisi gembili yang lebih banyak dapat memberikan sifat alir yang baik. Syarat serbuk yang sangat 
baik mempunyai waktu alir $\leq 10$ detik (Sulaiman, 2007). Persamaan yang diperoleh adalah persamaan linier berdasarkan model dari software Design Expert :

$Y=4,5873(A)+3,4451(B)$

Keterangan :

$\mathrm{A}=$ Komposisi Gembili

$\mathrm{B}=$ Komposisi Ganyong

Persamaan nilai waktu alir bermakna jika kenaikan komposisi gembili dan ganyong dapat meningkatkan waktu alir granul, hal ini ditunjukkan dengan koefisien yang bernilai positif. Gembili memiliki nilai Koefisien yang paling tinggi $(+4,58)$, sehingga Gembili memiliki efek dominan dalam meningkatkan waktu alir granul.

\subsubsection{Keseragaman bobot}

Uji keseragaman bobot dilakukan untuk melihat keseragaman dosis obat yang masuk kedalam tubuh sehingga dosis setiap tablet diharapkan sama dan sesuai dengan keamanan terapi dari sediaan tablet tersebut. Hasil pengujian menunjukkan bahwa masing-masing formula (tabel 3) memenuhi persyaratan Farmakope Indonesia edisi III, yaitu tidak lebih dari dua tablet yang menyimpang dari bobot rata-ratanya lebih dari 5\% dan tidak ada satu tablet pun yang menyimpang dari bobot rata-ratanya lebih dari $10 \%$. Persamaan yang diperoleh adalah cubic berdasarkan model dari software Design Expert;

$\mathrm{Y}=\mathbf{5 0 4 , 2 7}(\mathrm{A})+496,78(\mathrm{~B})+\mathbf{1 8 , 7 2}(\mathrm{AB})-40,56 \mathrm{AB}(\mathrm{A}-\mathrm{B})$

Keterangan :

A = Komposisi Gembili

$\mathrm{B}=$ Komposisi Ganyong

Berdasarkan persamaan (3) dapat terlihat interaksi antara komponen yang dioptimasi berpengaruh terhadap respon keseragaman bobot. Gembili dan ganyong keduanya menunjukkan koefisien positif. Penambahan kedua komposisi gembili dan ganyong akan meningkatkan keseragaman bobot, interaksi kedua komposisi gembili dan ganyong dapat meningkatkan keseragaman bobot, hal ini ditunjukkan dengan koefisien yang bernilai positif, sedangkan interaksi yang lebih kompleks antara komposisi gembili dan ganyong dengan melibatkan interaksi selisih komposisi gembili dan ganyong menghasilkan respon negatif $(-40,56)$ yang artinya dapat menurunkan keseragaman bobot. 


\subsubsection{Waktu hancur}

Uji waktu hancur dilakukan untuk mengetahui lamanya waktu hancur tablet dalam tubuh. Tablet yang tidak bersalut waktu yang diperlukan untuk hancur 6 tablet $\leq 15$ menit. Pada tabel 3 , menunjukkan bahwa formula I, II, III, IV, V, VI, VII, dan VIII tidak hancur selama $\leq 15$ menit. Persamaan yang diperoleh adalah cubic berdasarkan model dari software Design Expert :

$$
\mathrm{Y}=\mathbf{8 , 7 8 2 9 4}(\mathrm{A})+3,333294(\mathrm{~B})-2,78118(\mathrm{AB})+\mathbf{1 9 , 6 0 0 0 0} \mathrm{AB}(\mathrm{A}-\mathrm{B})
$$

Keterangan :

A = Komposisi Gembili

$\mathrm{B}=$ Komposisi Ganyong

Persamaan (4) dapat terlihat interaksi antara komponen yang dioptimasi berpengaruh terdahap respon waktu hancur. Komposisi gembili dan ganyong masing-masing menunjukkan nilai positif. Penambahan kedua komposisi akan meningkatkan waktu hancur, tetapi interaksi dari komposisi gembili dan ganyong dapat mengurangi waktu hancur, hal ini ditujukkan dengan koefisien yang bernilai negatif, sedangkan interaksi yang lebih kompleks antara komposisi gembili dan ganyong dengan melibatkan selisih antara komposisi gembili dan ganyong menghasilkan respon positif $(+19,60)$ yang artinya dapat meningkatkan waktu hancur tablet.

\subsection{Pemilihan formula optimum dan uji sifat fisik}

Berdasarkan parameter respon yang dilakukan maka selanjutnya adalah penentuan perbandingan optimum dengan menentukan beberapa kriteria, sehingga didapatkan nilai respon tertiggi yaitu desirability mendekati satu. Tabel 5 menunjukkan Formula hasil prediksi Design Expert Version 9.0 Trial dengan Formula Optimum. Formula optimum berdasarkan analisa SLD adalah perbandingan pati umbi gembili : ganyong $(82,11 \%: 17,89 \%)$. Formula optimum selanjutnya dibandingkan dengan formula prediksi SLD dengan analisa statistika uji-t untuk mengetahui apakah memiliki perbedaan yang signifikan $(\alpha>0,05)$. Tabel 5 menunjukkan hasil bahwa antara formula prediksi dengan formula uji (optimum) tidak memiliki perbedaan yang signifikan.

Tabel 5. Sifat fisik granul dan tablet Ibuprofen formula optimum dengan perbandingan bahan pengisi gembili dan ganyong $(82,11 \%: 17,89 \%)$

\begin{tabular}{|c|c|c|c|c|}
\hline Sifat Fisik & $\begin{array}{c}\text { Formula } \\
\text { Optimum }\end{array}$ & $\begin{array}{c}\text { Formula } \\
\text { Prediksi }\end{array}$ & $\begin{array}{c}\text { Signifikansi } \\
(\alpha>0,05)\end{array}$ & Kesimpulan \\
\hline $\begin{array}{c}\text { Waktu Alir } \\
\text { (detik) }\end{array}$ & $4,92 \pm 0,45$ & 4,38 & 0,178 & $\begin{array}{c}\text { Tidak berbeda } \\
\text { signifikan }\end{array}$ \\
\hline $\begin{array}{c}\text { Keseragaman } \\
\text { Bobot (mg) }\end{array}$ & $501,72 \pm 2,29$ & 501,82 & 0,929 & $\begin{array}{c}\text { Tidak berbeda } \\
\text { signifikan }\end{array}$ \\
\hline $\begin{array}{c}\text { Waktu Hancur } \\
\text { (menit) }\end{array}$ & $9,16 \pm 0,75$ & 9,24 & 0,845 & $\begin{array}{c}\text { Tidak berbeda } \\
\text { signifikan }\end{array}$ \\
\hline
\end{tabular}




\subsection{Sifat fisik granul dan tablet Ibuprofen formula optimum}

\subsubsection{Sudut diam granul}

Hasil yang didapat dari sudut diam adalah $26,96^{0}$ nilai ini menunjukkan sudut diam dapat diterima. Nilai yang dapat diterima antara $20-30^{\circ}$ dan nilai sampai $40^{\circ}$ menunjukkan potensial aliran yang kurang baik. Penambahan bahan pelicin dapat mempercepat pengeluaran granul dan jatuhnya granul dapat membuat semakin besar diameter granul dan memperpendek tinggi tumpukan sehingga sudut diam semakin kecil.

\subsubsection{Kekerasan tablet formula optimum}

Kekerasan tablet merupakan parameter yang digunakan menggambarkan ketahanan tablet terhadap tekanan mekanik seperti goncangan dan terjadinya keretakan tablet selama pengemasan, penyimpanan, dan penyaluran kepada konsumen. Kekerasan ini dipakai sebagai ukuran dari tekanan pengempaan. Semakin besar tekanan yang diberikan akan meningkatkan kekerasan tablet. Berdasarkan pemeriksaan kekerasan formula tablet ibuprofen optimum memiliki kekerasan 7,45 kg. Kekerasan formula optimum ini telah memenuhi persyaratan, yaitu memiliki tekanan antara 4-8 kg untuk tablet bukan salut.

\subsection{3. kerapuhan tablet formula optimum}

Kerapuhan merupakan parameter yang baik untuk mengetahui ketahanan tablet selama proses pengemasan dan distribusi tablet yang tahan dan tidak rapuh, karena tablet yang rapuh akan terkikis atau menyerpih bahkan bisa pecah ketika mengalami pengikisan di pengemasan dan guncangan saat distribusi. Semakin tinggi kekerasan tablet maka kerapuhan akan semakin kecil. Dari hasil kerapuhan tablet didapatkan nilai sebesar $0,81 \%$, dimana tablet memenuhi syarat kerapuhan yaitu tidak lebih dari $1 \%$.

\subsection{Penetapan kadar zat aktif dan profil disolusi tablet Ibuprofen formula optimum}

Penetapan kadar zat aktif merupakan persyaratan yang harus dipenuhi untuk menjamin kualitas sediaan obat. Sediaan obat yang berkualitas baik akan menunjang tercapainya efek terapetik yang diharapkan. Salah satu persyaratan mutu adalah harus memenuhi persyaratan kadar seperti yang tercantum dalam Farmakope Indonesia edisi V tahun 2005. Penentuan panjang gelombang serapan maksimum ibuprofen dalam $\mathrm{NaOH} 0,1 \mathrm{~N}$ diperoleh spektrum serapan maksimum $224 \mathrm{~nm}$ dengan konsentrasi $32 \mu \mathrm{g}$, dan absorbansi yang diperoleh sebesar 0,483 . Persamaan garis yang didapat adalah $\mathrm{y}=0,0265 \mathrm{x}-0,0457$ dengan nilai regresi $\mathrm{r}=$ 0,9979. Hasil penetapan kadar zat aktif diperoleh kadar ibuprofen dalam tablet antara 92,49\%$105,76 \%$. Dari persyaratan yang tertera dalam Farmakope Indonesia edisi V, tablet ibuprofen 
tidak kurang dari 90,0\% dan tidak lebih dari $110 \%$. Artinya kadar zat aktif dalam ibuprofen memenuhi persyaratan.

Uji disolusi adalah suatu metode in vitro yang digunakan untuk mengetahui obat dari bentuk sediaan menjadi bentuk yang terlarut. Semakin lama waktu uji disolusi maka semakin banyak zat aktif yang terlarut dalam cairan tubuh. Penentuan panjang gelombang serapan maksimum ibuprofen dalam dapar fosfat $\mathrm{pH}$ 7,2 diperoleh spektrum serapan maksimum $222 \mathrm{~nm}$ dengan konsentrasi $32 \mu \mathrm{g}$, dan absorbansi yang diperoleh sebesar 0,574. Persamaan garis yang didapat adalah $y=0,0267 x+0,0127$ dengan nilai regresi $r=0,9995$. Hasil penetapan uji disolusi kadar zat aktif yang diperoleh, kadar ibuprofen dalam tablet antara 0\%-95,67\%.

Peryaratan disolusi tablet yang ideal tidak kurang dari $80 \%$ dari jumlah yang tertera dilabel yang akan terdisolusi dalam 60 menit. Pada gambar 4, menunjukkan bahwa tablet formula optimum mengalami peningkatan, dan pada menit ke 60 zat aktif yang terlarut mencapai 95,67\%, artinya sudah sesuai dengan persyaratan. Hasil persen efisiensi disolusi (\%DE) pada menit ke 60 sebesar 78,25\%. Hasil uji disolusi tablet ibuprofen dengan kombinasi bahan pengisi pati umbi gembili-ganyong menandakan bahwa pati umbi gembili-ganyong dapat digunakan sebagai alternatif bahan pengisi tablet.

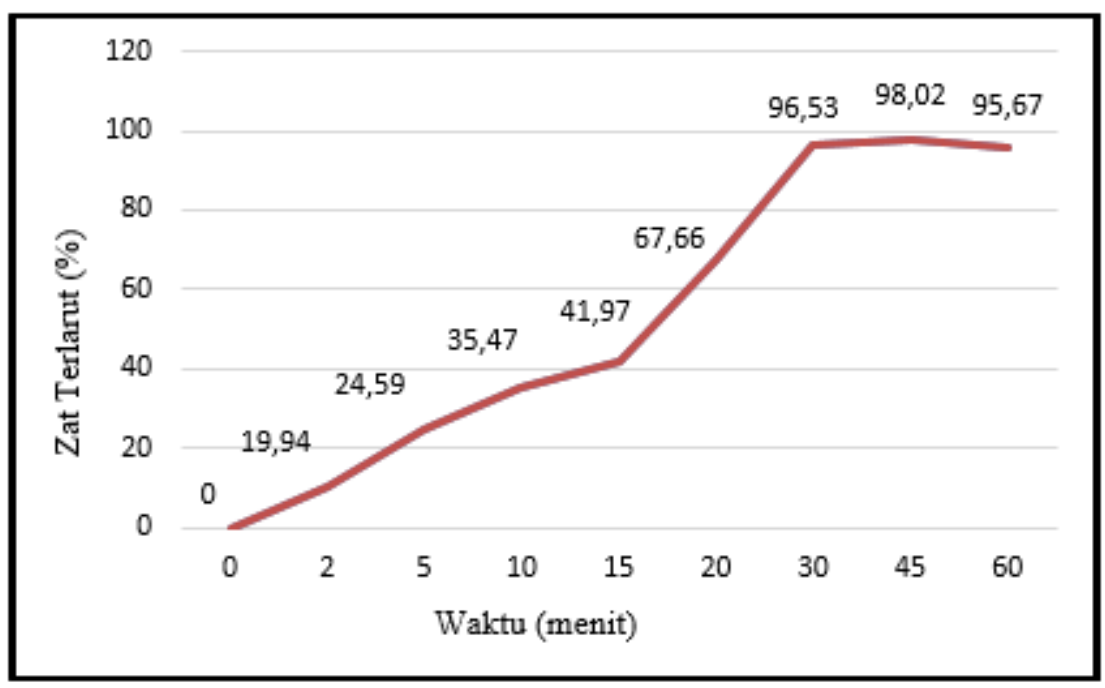

Gambar 1. Grafik disolusi tablet ibuprofen formula optimum (kombinasi bahan pengisi gembili:ganyong $82,11 \%: 17,89 \%$

\section{Kesimpulan}

Berdasarkan hasil penelitian disimpulkan bahwa tablet formula optimum yang mengandung bahan pengisi kombinasi pati gembili-ganyong pada perbandingan (82,11\%:17,89\%) memenuhi persyaratan tablet yang baik dengan nilai waktu alir 4,92 $\pm 0,46$ detik; sudut diam 26,96 $\pm 1,35^{0}$; keseragaman bobot sebesar 501,717 $\pm 2,29 \mathrm{mg}$; kekerasan 7,45 
$\pm 0,38 \mathrm{~kg}$; kerapuhan $0,81 \pm 0,01 \%$; waktu hancur $9,16 \pm 0,75$ menit, kadar zat aktif 92,49\%$105,76 \%$ dan nilai disolusi \%DE sebesar 78,25\%.

\section{Ucapan Terimakasih}

Program Studi S1 Farmasi, Fakultas Matematika dan Ilmu Pengetahuan Alam, Universitas Sebelas Maret, Surakarta.

\section{Daftar Pustaka}

Ansel, H.C., Allen, L.V., dan Popovich, N.G. 2013, Bentuk Sediaan Farmasetis dan Sistem Penghantar Obat, diterjemahkan oleh Hafshah Nurul Afifah, Tri Rahayu Ningsih Edisi 9., EGC, Jakarta. 243, 254, 258.

Departemen Kesehatan RI. 2014, Farmakope Indonesia Edisi Kelima, Departemen Kesehatan RI, Jakarta. 54. 541

Ferdiansyah, Rival. Yola D.P, Syarif H., Angga J. 2017, Penigkatan Kelarutan dan Disolusi Ibuprofen melalui Pembentukan Mikropartikel Metode Emulsification-Ionic-Gelation Menggunakan Polivinil Alkohol (PVA) sebagai Polimer dan Tripolifosfat (TPP) sebagai Agen Crosslink, Jurnal Sains dan Teknologi Farmasi Indonesia 4 (3) : 188-133.

Lachman L., Lieberman H.A., Kanig J.L. 2008, Teori dan Praktek Farmasi Industri diterjemahkan oleh Suyatni., Edidi III., UI Press, Jakarta. 934-935.

Mullarney MP, Hancock BC, Carlson GT, Ladipo DD, Langdon BA. 2003, The Powder Flow And Compact Mechanical Properties Of Sucrose and Three High-Intensity Sweeteners Used In Chewable Tablets, Int J Pharm 257 : 227-236.

Sulaiman, T.N.S. 2007, Teknologi dan Formulasi Sediaan Tablet, Laboratorium Teknologi Farmasi UGM, Yogyakarta.

Suihko, E., Lehto, V.P., Ketolainen, J., Laine, E., Paronen, P. 2001, Dynamic Solid- State and Tabletting Properties Of Four Theophylline Forms, Int. J. Pharm 217 : 225-236.

Richana, N., dan Sunarti, T.C. 2004, Karakterisasi Sifat Fisiko kimia tepung Umbi dan Tepung Pati Dari Umbi Ganyong, Suweg, Ubi kelapa dan Gembili, J.Pascapanen 1(1) : 29-37.

Richana, N. 2012, Araceae and Dioscorea: Manfaat Umbi-Umbian Indonesia, Penerbit Nuansa, Bandung.

Rohmah, M. 2013, Kajian Kandungan Pati, Amilosa Dan Amilopektin Tepung Dan Pati Pada Beberapa Kultivar Pisang (Musa spp), Prosiding Seminar Nasional Kimia, ISBN : 978-60219421-0-9.

Wilmana, P.F., dan Gan, S.G. 2007, Analgesik-Antipiretik Analgesik AntiInflamasi Nonsteroid dan Obat Gangguan Sendi Lainnya. Dalam: Gan, S.G., Editor. Farmakologi dan Terapi Edisi 5., Gaya Baru, Jakarta. 230- 240. 